\title{
A Canadian range extension for Wormslug (Boettgerilla pallens; Gastropoda: Stylommatophora: Boettgerillidae)
}

\author{
Paul M. Catling ${ }^{1, *}$ and Brenda Kostiuk ${ }^{1}$ \\ ${ }^{1} 170$ Sanford Avenue, Ottawa, Ontario K2C 0E9 Canada \\ *Corresponding author: brenda.kostiuk@gmail.com \\ Catling, P.M., and B. Kostiuk. 2018. A Canadian range extension for Wormslug (Boettgerilla pallens; Gastropoda: Stylommato- \\ phora: Boettgerillidae). Canadian Field-Naturalist 132(3): 264-267. https://doi.org//10.22621/cfn.v132i3.1993
}

\begin{abstract}
The introduced Wormslug (Boettgerilla pallens Simroth, 1912) is reported from Quebec, Canada, for the first time, from two closely situated localities in Gatineau Park. It was previously reported from the Vancouver area of British Columbia and, very recently, from Newfoundland. Within the Americas, the species has been reported from northern California, Mexico, and Colombia, and, because it is easily overlooked, likely occurs elsewhere in North America, especially in the eastern United States. In Quebec, it was found in a natural Sugar Maple (Acer saccharum Marshall) woodland and an ornamental garden. Wormslug likely reached both sites with shrub plantings from commercial nurseries, probably quite recently, because the invasive spread of the species, worldwide, has occurred mostly during the last few decades. Although the woodland where it occurred is dominated by native plants, the gastropod fauna there is mainly introduced. Identification, characteristics, and ecology of Wormslug are discussed. The potential for impact on native soil and soil surface organisms, including native terrestrial slugs and snails, is noted.
\end{abstract}

Key words: Wormslug; Boettgerilla pallens; Quebec; introduced; invasive; slug; spread; distribution; ecology

During a general biodiversity reconnaissance in Gatineau Park, Quebec, in September and October 2017, we discovered two closely situated occurrences of Wormslug (Boettgerilla pallens Simroth, 1912). This largely subterranean, worm-like slug (Figure 1), which is native to southeastern Europe, has expanded its range remarkably over the past few decades (e.g., Kerney 1999; Reise et al. 2000; Maunder et al. 2017). The newly discovered populations in Quebec are $\sim 3500 \mathrm{~km}$ east of previous known occurrences in the Vancouver area of British Columbia (Reise et al. 2000) and $\sim 1790 \mathrm{~km}$ west of a recently reported occurrence in Newfoundland (Maunder et al. 2017). The nearest known United States location is in northern California (McDonnel et al. 2014), $\sim 3800 \mathrm{~km}$ to the west. It is an easily overlooked species and likely occurs elsewhere in North America, particularly in the eastern United States.

Only two species of Boettgerilla are known, both originating in the Caucasus Mountains, east of the Black Sea. Boettgerilla pallens may also be native in the relatively nearby mountains of Crimea (Balashov and Baidashnikov 2012). Although B. pallens has expanded its world range dramatically during the last century, Boettgerilla compressa Simroth, 1910 has not yet been reported from outside of the southwestern Caucasus Mountains (Sysoev and Schileyko 2009). Boettgerilla compressa differs (Sysoev and Schileyko 2009) from B. pallens in that the adults are $\sim 20 \mathrm{~mm}$ long when contracted instead of $10 \mathrm{~mm}$ long, pale brownish-yellow instead of pale grey, and laterally compressed across the back (hence the name) instead of equilaterally triangular (Simroth 1912: 121) to somewhat cylindrical. Al- though our specimens seem best placed with $B$. pallens, and that is the species associated with all records of range expansion, we note that the distinctive features are size and age-related, and that $B$. compressa may benefit from additional taxonomic study.

The only other slug present in the general Gatineau Park region of Quebec that is likely to be confused with B. pallens is the pale greyish Pale Mantleslug (Pallifera dorsalis (A. Binney, 1842)). The latter differs in being shorter when extended, in lacking a keeled tail, and in having a rounded mantle that extends almost to the tip of the tail. Boettgerilla pallens is very slender and has a keel on the back half of its body extending from behind the mantle to the tip of the tail. In addition, the mantle has a different texture with concentric ridges (Figure 1a,b) and tapers to a broad point distally.

The adult Wormslugs found at the Meech Lake site in Gatineau Park were $20-45 \mathrm{~mm}$ long and 2-3 mm wide when extended. Most were light greyish with the front of the head, front of the mantle, keel, and tip of the tail being darker grey (Figure 1a). Two of the longest individuals, both $45 \mathrm{~mm}$ when extended, were a darker grey overall and had some brownish colouring (Figure 1b). Individuals that we thought likely to be juvenile were $\sim 20 \mathrm{~mm}$ when extended and mostly white with yellowish internal organs visible through the whitish translucent body (Figure 1d). Size and colour are age-related in $B$. pallens, with "juveniles" being distinctly whitish (Gunn 1992; Rowson et al. 2014).

When picked up with forceps (or otherwise irritated) the body behind the mantle compressed laterally, becoming $1 \mathrm{~mm}$ thick in dorsal view (and $4 \mathrm{~mm}$ wide in

A contribution towards the cost of this publication has been provided by the Thomas Manning Memorial Fund of the Ottawa Field-Naturalists' Club. 

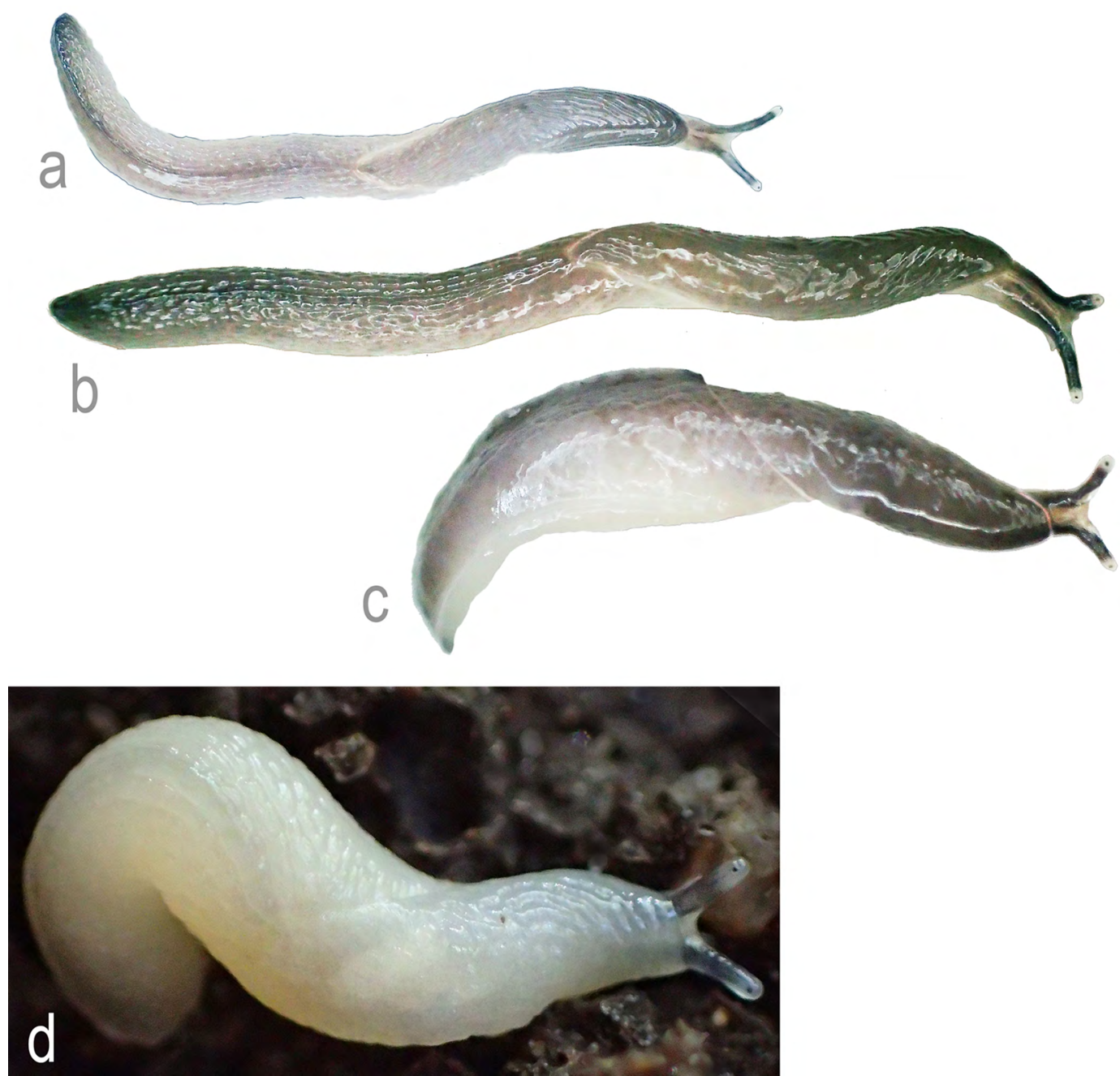

Figure 1. Wormslugs, Boettgerilla pallens, from Meech Lake, Gatineau Park, Quebec. a. Mostly pale grey and $30 \mathrm{~mm}$ when extended. b. Darker and brownish and $45 \mathrm{~mm}$ when extended. c. Same individual as b but with back half laterally compressed and keel raised as a thin, long dorsal fin. $d$. A whitish and semi-transparent juvenile Wormslug showing internal organs; the animal was $20 \mathrm{~mm}$ in length when extended. Photos: P.M. Catling and B. Kostiuk.

lateral view), and the keel became prominently raised (Figure 1c). When the head was touched, it withdrew under the mantle which extended and flattened or folded over the head like an envelope so that its sides met.

A number of illustrations are available in addition to our photographs (Figure 1) to assist in identification including Simroth (1912: Plate 3, Figure 50, Plate 8, Figure 32), Wiktor (1959: Figures 6 and 7, 1961: Figures 3-5), Reise et al. (2000: Figure 1), Barker and Efford (2004: Figure 6.8), Grimm et al. (2009: Plate 1), Sysoev and Schileyko (2009), Balashova and Baidashnikov (2012: Figure 1b), and Maunder et al. (2017: Figures $1-4)$.

Since expanding its range from its native Caucasus Mountains, apparently during the last 100 years, B. pal- lens has been reported from much of central and western Europe, ranging north to Scandinavia (Kerney and Cameron 1979; Reise et al. 2000; Eversham 2012; Anderson 2016; Maunder et al. 2017). It is also known from the Canary Islands (Margry 2014). In the Americas, it has most recently been discovered in St. John's, Newfoundland (Maunder et al. 2017). Additional occurrences have been reported from southwestern British Columbia (Reise et al. 2000; Grimm et al. 2009; Maunder et al. 2017), California (McDonnell et al. 2014), Mexico (Araiza-Gómez et al. 2016), and Colombia (Hausdorf 2002).

In its introduced range, B. pallens occupies anthropogenic habitats, including gardens, greenhouses, semiwild city parks, and plant nurseries. However, in the 
Americas, in particular, it also occupies a number of "natural-looking habitats" (Maunder et al. 2017). It is said to have successfully penetrated forests and other natural habitats in recently colonized parts of Europe (Grimm et al. 2009).

At the Meech Lake, Gatineau Park site, the habitat where it was found is mesic woodland dominated by Sugar Maple (Acer saccharum Marshall) and Eastern White Cedar (Thuja occidentalis L.). Prominent herbs included: Blue-stemmed Goldenrod (Solidago caesia L.), Common Lady Fern (Athyrium filix-femina (L.) Roth ex Mertens), Drooping Woodland Sedge (Carex arctata Boott), Interrupted Fern (Osmunda claytoniana L.), Large False Solomon's Seal (Maianthemum racemosum (L.) Link subsp. racemosum), Lindley's Aster (Symphyotrichum ciliolatum (Lindley) Á. Löve \& D. Löve), and Tall Rattlesnakeroot (Nabalus altissimus (L.) Hooker). This habitat is in a valley where a small stream cascades over granite boulders at the base of a steep north-facing slope.

These Wormslugs were found $\sim 20-70 \mathrm{~m}$ along a trail from the parking area into natural forest. Although the forest showed no signs of recent disturbance, it was apparently subject to domestic cutting a little more than 100 years ago. The landscape may have been much more open at that time, as a consequence of this wood cutting. Although the habitat now appears essentially natural, the only terrestrial snails present (observed in a 1-h search in an area of $0.40 \mathrm{ha}$ ) were: the possibly introduced locally (Holarctic) Glossy Pillar (Cochlicopa lubrica (Müller, 1774); $n=7$ ); possibly introduced (Holarctic) Black Gloss (Zonitoides nitidus (Müller, 1774); $n=3$ ); and native Quick Gloss (Zonitoides arboreus (Say, 1817); $n=6$ ). The slugs present were all introduced including Garden Arion (Arion hortensis Férussac 1819, sensu lato; $n=50$ ); Dusky Arion (Arion subfuscus/fuscus (Draparnaud, 1805); $n=1$ ); and Grey Fieldslug (Deroceras reticulatum (Müller, 1774); $n=5$ ).

At the Old Chelsea Picnic Area site, also in Gatineau Park, the habitat where the Wormslugs were found was an ornamental garden dominated by a variety of planted perennials including: Variegated Goutweed (Aegopodium podagraria L.), daylilies (Hemerocallis spp.), geraniums (Geranium spp.), Eastern Purple Coneflower (Echinacea purpurea (L.) Moench), and Eastern White Cedar (Thuja occidentalis L.). This garden is more than 20 years old and has undergone many recent changes including additions of plants and rearrangement of paths. The terrestrial gastropod fauna (observed in a $0.5-\mathrm{h}$ search in an area of $\sim 0.10 \mathrm{ha}$ ) is mostly introduced, including: possibly introduced (Holarctic) Glossy Pillar $(n=2)$; introduced Hairy Hellicid (Trochulus hispi$d u s$ (L., 1758)); $n=3)$; possibly introduced (Holarctic) Black Gloss $(n=1)$; and introduced Garlic Glass-snail (Oxychilus alliarius (Miller, 1822); $n=1$ ). The slugs present were: the introduced Grey Fieldslug $(n=15)$; and native or possibly introduced (Holarctic) Meadowslug (Deroceras laeve (Müller, 1774); $n=1$ ).
All these Wormslugs were found under rocks or logs more or less buried in the soil. This species is known to use earthworm burrows (Gunn 1992; Shikov 2007) and we found them in rodent burrows, as well as other spaces in soil and debris. They have been reported to descend to $60 \mathrm{~cm}$ below the soil surface (Gunn 1992). Earthworms (all introduced) were frequent at both Gatineau Park sites, and there were no accumulations of decomposing leaf litter at either site, so no litter samples were collected or available to search for minute snail species.

Wormslugs typically spread by transport in soil associated with cultivated plants (Reise et al. 2000). In 1900, the Meech Lake site was part of the Blanchet Farm where pears, plums, and apples had long been introduced. Along the southern shore of Meech Lake, there are currently many cottages with plantings of introduced perennials, shrubs, and trees in rock gardens. These plantings were probably built up throughout the last century judging by the age of some cottages. Within the last two decades, the Blanchet homesite was converted into a parking lot for beach access, and various shrubs were planted around it, including Red-osier Dogwood (Cornus sericea L.), Rugosa Rose (Rosa rugosa Thunberg), and Nannyberry (Viburnum lentago L.). Although some of the planted shrubs are native, they all likely originated from commercial nurseries potentially harbouring non-native gastropods. The Chelsea site has perennials that were probably introduced from one or more commercial nurseries that also probably had populations of introduced gastropods (as all local nurseries do). Thus both occurrences are consistent with the general explanation for the spread of Wormslugs.

These burrowing slugs are said to feed on fungi, micro-organisms, roots, decaying vegetation, eggs of other gastropods, and possibly invertebrates (Barker and Efford 2004; Eversham 2012). They are also reported to appear at the surface at night and feed on mediumsized snails (Shikov 2007). Unlike many other slugs, they are said not to survive in captivity on oatmeal, mushrooms, and carrot (Eversham 2012). Although Wormslug has not definitely been implicated as an agricultural pest, there does seem to be a potential for impact on native soil and soil surface organisms including native terrestrial snails. It may spread rapidly as appears to be the case following initial detection elsewhere (e.g., Eversham 2012).

\section{Voucher specimens}

Canada, Quebec: Gatineau Park: North-facing slope at the west end of Meech Lake above the Blanchet homestead parking area at the start of Sentier des Loups, $45.5425^{\circ} \mathrm{N}, 75.9107^{\circ} \mathrm{W}$, Sugar Maple woods by stream, 20 September 2017, P.M. Catling 2017120 and B. Kosti$u k$, two specimens preserved of eight - Canadian Museum of Nature (CMNML 2018-1704). Old Chelsea Picnic Area, $45.5012^{\circ} \mathrm{N}, 75.8128^{\circ} \mathrm{W}$, ornamental gar- 
den, 9 October 2017, P.M. Catling 2017148 and B. Kostiuk, one specimen preserved of three - Canadian Museum of Nature (CMNML 2018-1703).

\section{Acknowledgements}

Stéphane Wojciechowski of Land Management, Gatineau Park issued permit 19365-1 for the collection of terrestrial gastropods in Gatineau Park. The park also provided facilities for a gastropod field workshop. John E. Maunder, Jeff Nekola, and Fred Schueler kindly commented on the manuscript.

\section{Literature Cited}

Anderson, R. 2016. Boettgerilla pallens Simroth 1912 Worm slug. MolluscIreland, National Museums Northern Ireland, Holywood, Down, Northern Ireland. Accessed 1 October 2017. http://www.habitas.org.uk/molluscireland/species. asp?ID=46.

Araiza-Gómez, V., E.A. Ruiz, E. Naranjo-García, and G. Zúñiga. 2016. Recent collecting reveals the presence of Boettgerilla pallens (Stylommatophora, Boettgerillidae) in Mexico. American Malacological Bulletin 33: 227-231. https://doi.org/10.4003/006.033.0215

Balashova, I.A., and A.A. Baidashnikov. 2012. The first findings of a slug Boettgerilla pallens (Stylommatophora, Boettgerillidae) in Crimea. Ruthenica 22: 111-114. Accessed 30 January 2019. https://www.biotaxa.org/Ruthen ica/article/view/3413.

Barker, G.M., and M.G. Efford. 2004. Predatory gastropods as natural enemies of terrestrial gastropods and other invertebrates. Pages 279-403 in Natural Enemies of Terrestrial Molluscs. Edited by M.G. Efford. CAB ebooks, CAB International, Wallingford, Oxfordshire, United Kingdom. https://doi.org/10.1079/9780851993195.0000

Eversham, B. 2012. Identifying British slugs. Accessed 10 February 2018. https://www.naturespot.org.uk/sites/default/ files/downloads/Identifying\%20British $\% 20$ Slugs $\% 20 \% 20$ 2012\%20version\%201.pdf.

Grimm, F.W., R.G. Forsyth, F.W. Schueler, and A. Karstad. 2009. Identifying Land Snails and Slugs in Canada. Canadian Food Inspection Agency, Ottawa, Ontario, Canada.

Gunn, A. 1992. The ecology of the introduced slug Boettgerilla pallens (Simroth) in North Wales. Journal of Molluscan Studies 58: 449-453. https://doi.org/10.1093/mollus/ 58.4.449

Hausdorf, B. 2002. Introduced land snails and slugs in Colombia. Journal of Molluscan Studies 68: 127-131. https:// doi.org/10.1093/mollus/68.2.127
Kerney, M.P. 1999. Atlas of the Land and Freshwater Molluscs of Britain and Ireland. Harley Books, Colchester, United Kingdom.

Kerney, M.P., and R.A.D. Cameron. 1979. A Field Guide to the Land Snails of Britain and Northwest Europe. Collins, London, United Kingdom.

Margry, C.J.P.J. 2014. First record of Boettgerilla pallens Simroth, 1912 (Gastropoda, Pulmonata, Boettgerillidae) on the Canary Islands. Basteria 78 (4-6): 57.

Maunder, J.E., R.G. Noseworthy, J.M.C. Hutchinson, and H. Reise. 2017. Terrestrial molluscs of the Province of Newfoundland and Labrador, Canada. Part 1: Boettgerillidae. Check List 13: 277-284. https://doi.org/10.15560/13. 4.277

McDonnell, R.J., D.G. Robinson, N. Barr, I. Tandingan, P. DeLey, and P.D. Paine. 2014. First report of the invasive slug Boettgerilla pallens Simroth, 1912 (Boettgerillidae) in the United States. American Malacological Bulletin 32: 209-210. https://doi.org/10.4003/006.032.0210

Reise, H., J.M.C. Hutchinson, R.G. Forsyth, and T. Forsyth. 2000. The ecology and rapid spread of the terrestrial slug Boettgerilla pallens in Europe with reference to its recent discovery in North America. Veliger 43: 313-318. Accessed 10 May 2017. https://biodiversitylibrary.org/page/ 42461023.

Rowson, B., J. Turner, R. Anderson, and B. Symondson. 2014. Slugs of Britain and Ireland: Identification, Understanding and Control. FSC Publications/National Museum of Wales, Telford, Wales.

Shikov, E.V. 2007. New finds of terrestrial molluscs (Gastropoda, Pulmonata) on the Russian Plain. Vestnik TSU. Biology and Ecology 6: 118-122 [in Russian].

Simroth, H. 1912. Neue Beiträge zur Kenntnis der Kaukasischen Nacktschneckenfauna. Volume 6). Mitteilungen des Kaukasischen Museums, St. Petersburg, Russia. Accessed 10 February 2016. https://biodiversitylibrary.org/page/116 53018.

Sysoev, A.V., and A.A. Schileyko. 2009. Land Snails of Russia and Adjacent Countries. Pensoft, Sofia/Moscow, Russia.

Wiktor, A. 1959. Boettgerilla vermiformis n. sp. (Mollusca, Pulmonata) ze Srodkowych Sudetów. Communications of the Poznañ Society of Friends of Science, Department of Mathematical and Natural Sciences No 4, Poznań, Poland.

Wiktor, A. 1961. Materialy do znajomósci rodzaju Boettgerilla Simroth, 1910 (Gastropoda, Limacidae). Annales Zoologici 19: $125-145$.

Received 21 October 2017

Accepted 10 July 2018 